\title{
Numerical modeling of slope stability incorporating complex reinforcement solution in high-risk failure area- unusual case study
}

\author{
Ngoc Anh Pham 1, Piotr Osinski ${ }^{2,}$, Ngoc Anh Do ${ }^{1}$, Eugeniusz Koda ${ }^{2}$, Manh Van \\ Nguyen ${ }^{1}$, Duc Van Bui ${ }^{1}$, Ngan Van Tao ${ }^{3}$
}

${ }^{1}$ Hanoi University of Mining and Geology, Hanoi, Vietnam

2 Warsaw University Of Life Sciences, Warsaw, Poland

${ }^{3}$ Fucons Foundation and Underground, Hanoi, Vietnam

\section{ARTICLE INFO}

Article history:

Received $15^{\text {th }}$ June 2021

Revised $16^{\text {th }}$ Sept. 2021

Accepted $14^{\text {th }}$ Oct. 2021

\section{Keywords:}

Electro-thermal,

LED driver,

Meaning-Time-To-Failure,

MTTF.

\section{ABSTRACT}

The rapid economic development of Vietnam triggers a number of challenges in all sectors including infrastructure design and execution. New development plans and lack of space in densely populated and economically valuable areas creates a need for complex engineering solutions to meet the demand. The present research is a case study investigating reengineered vast natural slope to meet all requirements for geotechnical safety such as maximum displacements and factor of safety. Complex ground conditions and significant dimensions of the slope made the entire structure very likely to cause major risk for the future development plan of the site. Due to complex conditions, the slope was divided into 4 main sections. Each section was reinforced using a combination of soil nails, ground anchors, drainage systems and micro piles, of $19 \mathrm{~m}$ for a single pile. Due to very much limited space available new geometry of the slope was designed for inclination reaching 1:0.3. Based on numerical modelling and computation the results revealed that the maximum lateral displacements felt in a range of $37-50 \times 10^{-3} \mathrm{~m}$ and the factor of safety was 1.56-1.65, depending on a section and analysed scenario. The computations allowed proposing combined geotechnical solutions for very much challenging sites, assuring high safety standards and fitting the entire design within a limited available area.

${ }^{*}$ Corresponding author

E-mail: piotr_osisnki@sggw.edu.pl

DOI: $10.46326 / J M E S .2021 .62(6) .07$ 


\section{Introduction}

According to the number of reports, Vietnam's economy has shown strong growth in $2019 \div 2020$. This is the effect of continuous high domestic demand, manufacturing enterprises growth and diversity in developing industries (Dhar, 2021; Nguyen et al., 2020a; 2020b). Despite the impact of recent pandemic circumstances Vietnam is considered to become the fastest growing economy in the South East Asia region (Seah, 2021; Nguyen, 2020b). To be able to follow an ongoing development many challenges will have to be faced. These also concerns geotechnical structures and soil mechanics which are an integrated part of infrastructure development (Berglund et al., 2020). With new development plans in densely populated and economically valuable areas and a shortage of available space, complex engineering solutions will be needed to meet the demand (Tang et al., 2018).

The case study investigated in the present paper is an excellent example of how the combination of sophisticated ground improvement methods could be applied in practice. The case study concerns vast slope stability issues caused by a number of factors like limited space available for earthworks, complex ground condition and large scale investment project, that is planned to be constructed at the study site. Bearing in mind all these issues and to assure the geotechnical safety of the slope a combination of slope reinforcement methods were proposed at the site these included: reengineering the geometry of the slope, installation of soil nails, ground anchors, drainage systems and micro piles (Blanco-Fernandez, 2011; Thyagaraj, 2019; Osinski et al., 2020). The paper aims to present the entire design process for such a complex approach. To meet the highest safety standards numerical computations were considered for most critical scenarios performed to come up with optimal and safe solutions. The geotechnical safety modelling and analyses concerned soil and structure lateral displacements predictions as well as the factor of safety computation, applying shear strength reduction approach using finite element method (Wan et al., 2010; Zetter et al., 2020; Zhang et al.,
2021). What makes the case study unusual is the scale and the scope of designing and execution works at the site. The combination of reinforcing approaches including the installation of $19 \mathrm{~m}$ long micro piles is found to be an unusual solution in Viet Nam. Complex ground conditions consisting of highly weathered soil, building a $19 \mathrm{~m}$ high slope of a valuable urban area, makes the entire analysis even more challenging.

\section{Material and methods}

\subsection{Study site}

The study site is located in the southeast part of Viet Nam in Ha Long City, Quang Ninh Province. The site is recognised a highly touristic region, that has been focusing lots of attention on infrastructural development in recent years.

The case study concerns a natural slope surrounding future planned development. The slope is considered vast, of $96 \mathrm{~m}$ length in, with its highest elevation point reaching $19 \mathrm{~m}$ from the ground level (crest of the slope located at +54.21 and lowest elevation at the toe of the slope is +35 ). Due to significant changes in the slope's elevations as well as to the complexity of the geometry of the slope, the slope was proposed to be divided into four lateral sections, namely:

- Section No. 1: from the elevation of 45.94 (point 4') to the level of 50.47;

- Section No. 2: from a point of level of 50.47 to 50.80 (point 3');

- Section No. 3: from a point of level of 50.80 to 52.83 (point 2');

- Section No. 4: from a point of level of 52.83 to 54.21 (point $\mathrm{H}$ );

The design level of the toe of slope was +35.00 . The sections and location are presented in Figure 1.

The site investigation performed at the site allowed identifying five major geotechnical layers. The ground conditions at the site were considered demanding due the presence of highly weathered lime stone layer located beneath the deposits of stiff clay.

4 major geotechnical layers from the top were stiff clay (down to $12 \mathrm{~m}$ ), weathered limestone (6 $\mathrm{m}$ thickness), extensive (14 m thickness) medium sand (dense), finishing with deposits of stiff clay with gravel layer. Details 


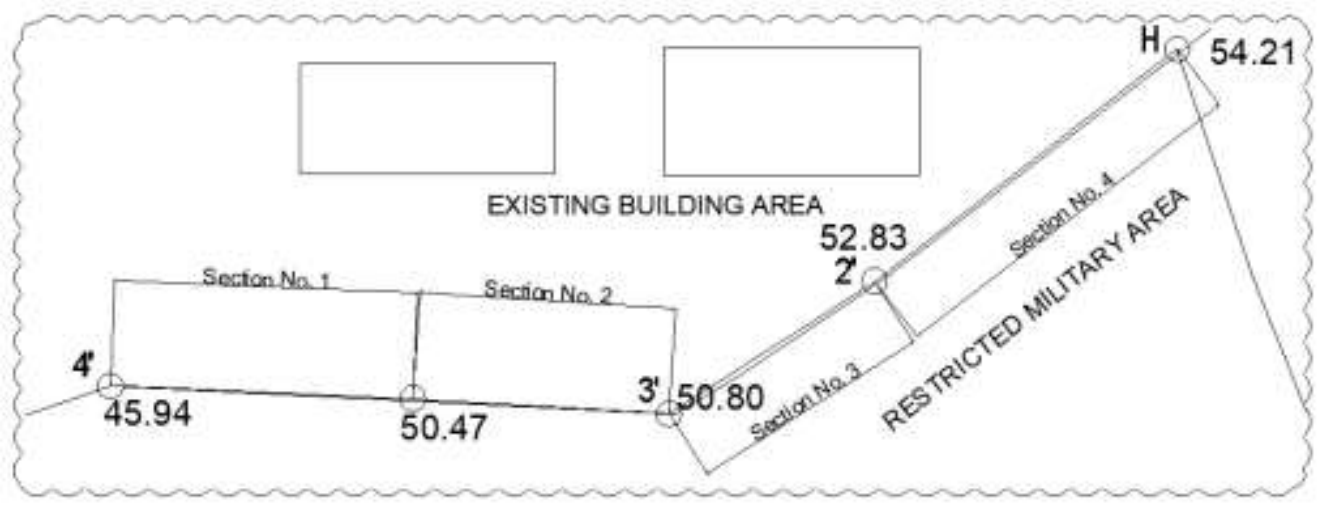

Figure 1. Aerial view of the study site.

including mechanical and physical parameters of soils building only the slope (used for modeling) are presented in Table 1.

Since the moisture content in this particular is changing frequently due to heavy rain frequent events, the content of the small particles could lead to a displacement or even slope failure. Surprisingly, there was no groundwater table found in all boreholes nearby the hill slope. The example of a soil profile for the study area is presented in Figure 2.

\subsection{Slope reinforcemnts methods}

Because the designed toe level was +35.00 , so the height to the crest of the slope, was considered significant compared to typical engineered slopes. Aiming at a long term geotechnical safety

\section{Table 1. Soil physical, mechanical and hydraulic} parameters used for modelling purposes.

\begin{tabular}{|l|c|c|c|}
\hline \multirow{2}{*}{ Prameter } & \multirow{2}{*}{ Unit } & \multicolumn{2}{|c|}{ Value } \\
\cline { 3 - 4 } & & Soil layer 1 & Soil layer 2 \\
\hline$\gamma_{\text {_unsat }}$ & {$\left[\mathrm{kN} / \mathrm{m}^{3}\right]$} & 19.0 & 20.0 \\
\hline$\gamma_{\text {_sat }}$ & {$\left[\mathrm{kN} / \mathrm{m}^{3}\right]$} & 19.5 & 20.5 \\
\hline E & {$\left[\mathrm{kN} / \mathrm{m}^{2}\right]$} & $3.0 \mathrm{E} 4$ & $4.0 \mathrm{E} 4$ \\
\hline c & {$\left[\mathrm{kN} / \mathrm{m}^{2}\right]$} & 16.0 & 18.0 \\
\hline$\varphi$ & {$[0]$} & 17.0 & 19.0 \\
\hline K & {$[\mathrm{m} /$ day $]$} & $1.0 \mathrm{E}-04$ & $1.0 \mathrm{E}-05$ \\
\hline$v$ & - & 0.25 & 0.25 \\
\hline R_inter & - & 0.7 & 0.7 \\
\hline
\end{tabular}

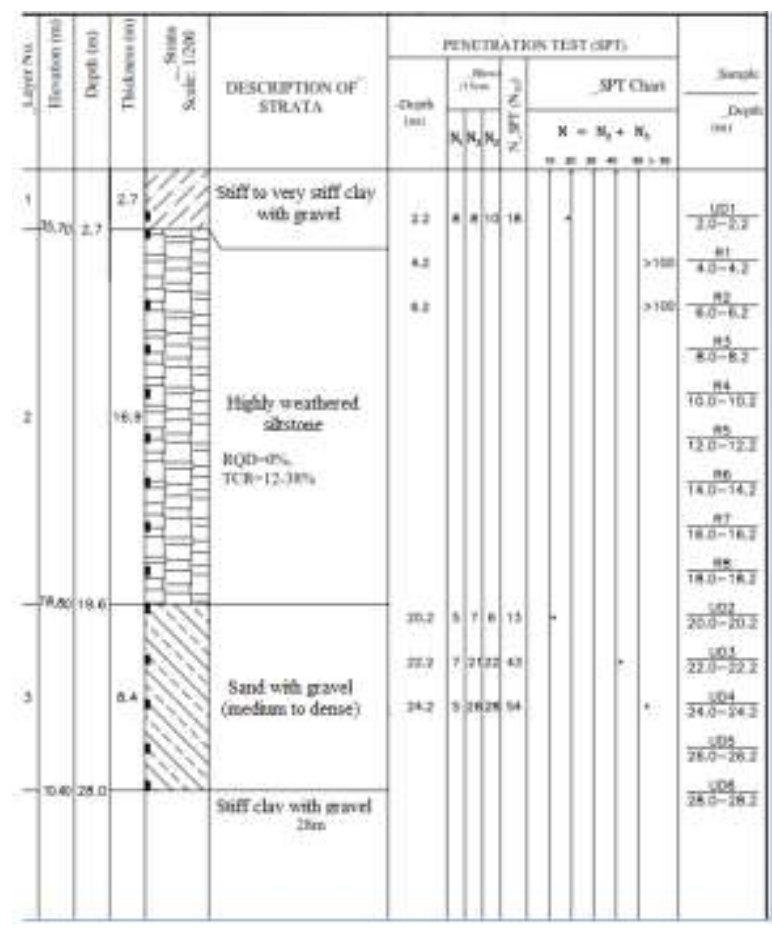

Figure 2. Example of the study site borehole profile.

performance, in this particular case several reinforcing techniques were employed including soil nailing, ground anchor, micropiles, back wall drainage system (Babu, 2004; Ellis, 2020; Bayesteh et al., 2021).

\subsubsection{Reinforcing approaches}

Due to confined space with restricted access, the potential impact on surrounding areas, low groundwater table, the techniques of soil nailing, ground anchor were chosen as a readable solution in this case. In addition, in order to prevent potential deep-seated slope failure, three rows of 
micropiles of $325 \mathrm{~mm}$ diameter were suggested in the design proposal. The geometry of a cut slope was reengineered to achieve a slope angle equal to 1:0.3 inclination. The entire height of the slope was divided into subsections $6 \mathrm{~m}$ high each. The same inclination was proposed to all the sections. all have the same slope angle of $73^{\circ}$, thus the slope is considered extremely steep requiring enough geotechnical safety assurance. To support the structure and improve the ground conditions even more and also to allow more space (by increasing the inclination) as well as to execute the micropile work, two berms with of $1.00 \mathrm{~m}$ width were designed at the level of +41.00 , and +47.00 . Figure 3 presents the entire reinforcing system applied at the slope in sections 3 and 4, a similar approach was used in sections 1 and 2 . Each of the sections is described in detail as follows: Slope's face No. 1 from the level of +35.00 to +41.00 . This lowest face of the hill slope is stabilized using two soil nail rows (nail diameter of $25 \mathrm{~mm}$, length of the nail is $9.0 \mathrm{~m}$ ); one ground anchor layer consisting of $8.0 \mathrm{~m}$ bond length and 8.0 free length, the designed force of the ground anchor layer is $250 \mathrm{kN}$. In order to prevent the general slope failure event, a row of micropile was proposed. The diameter and length of the micropile are $325 \mathrm{~mm}, 7.0 \mathrm{~m}$, respectively. The face slope is consequently protected from infiltration water by using a concrete layer of 400 $\mathrm{mm}$, with drainage layers behind the wall. Slope's face No. 2 (middle face slope) from the level of +41.00 to +47.00: This middle face of the hill slope is stabilized using two soil nail rows (nail diameter of $25 \mathrm{~mm}$, length of nails are $8.0 \mathrm{~m}$ and $9.0 \mathrm{~m}$ ); one ground anchor layer consists of $8.0 \mathrm{~m}$ bond length and 8.0 free length, the design force of ground anchor is $260 \mathrm{kN}$. A row of micropile is proposed of diameter and length of $325 \mathrm{~mm}, 13.0$ $\mathrm{m}$, respectively. The face slope is covered using a

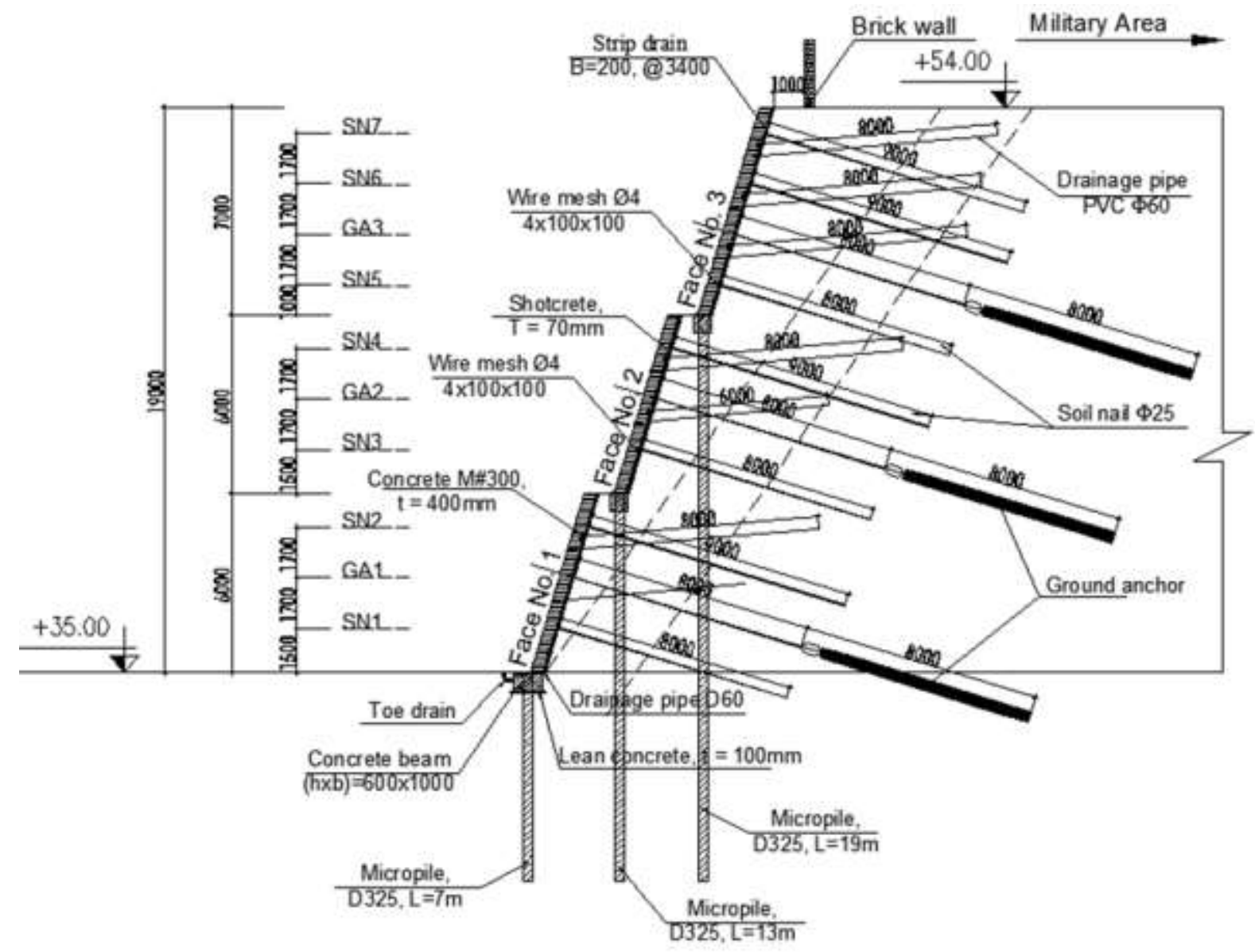

Figure 3. Details of reinforcing approach for slope located in section No.3, and No.4 (acc the locations presented in Figure 1). 
concrete layer of $400 \mathrm{~mm}$. Slope's face No. 3, starts from the level of +47.00 . This face is stabilized using three soil nail rows, with a nail diameter of $25 \mathrm{~mm}$ and length of $8.0 \mathrm{~m}, 9.0 \mathrm{~m}$ and $9.0 \mathrm{~m}$. One ground anchor layer consists of $8.0 \mathrm{~m}$ bond length and 8.0 free length, the design force of this ground anchor layer is $250 \mathrm{kN}$. A row of micropile 325 $\mathrm{mm}$ in diameter and $19 \mathrm{~m}$ long were proposed. The face slope as in previse sections is protected using a $400 \mathrm{~mm}$ concrete layer.

\subsubsection{Drainage system}

Increasing moisture content in natural slopes has been recognised as one of the most crucial factors triggering severe slope failures and landslides the slope stability (Fredlund et al., 1996; Crosta et al., 2008; Elia et al., 2018). One of the solutions minimising the failure risk, by controlling the groundwater flow is a drainage system without a doubt. For structures as this presented in the study, the drainage is usually installed behind the soil nail wall to collect perched groundwater or infiltrated surface water that is present behind the facing and directs the collected groundwater away from the wall (Dai et al., 2002; Rahardjo et al., 2003). Based on the soil nail reference manual (Lazarte et al., 2015), groundwater condition and the mechanical parameters of soil material (stiff to very stiff silty clay), with the amount of sand occupying $60 \%$ of soil samples, the drainage system proposed in the present case study consists of two drainage PVC pipe rows to be installed at each sub-slope with diameter and length of pipes of $60 \mathrm{~mm}$, and $8.0 \mathrm{~m}$, respectively. The inclination angle of a drainage pipe is $5-10^{0}$. To safely manage the infiltration and runoff water, a strip drain having a width of 200 $\mathrm{mm}$ and spacing of $3.400 \mathrm{~mm}$ was also proposed as a solution for uncontrolled water flow along with the soil profile.

\section{Results}

\subsection{Calculation process and evaluating slope stability}

To calculate and evaluate the slope stability, the geotechnical software Plaxis 2D was employed (Brinkgreve, 2010). The geometry of the slope, reinforcing elements, berms, investigation ground conditions data were incorporated into the finite element model. The general view of the model with all its features is presented in Figure 4.

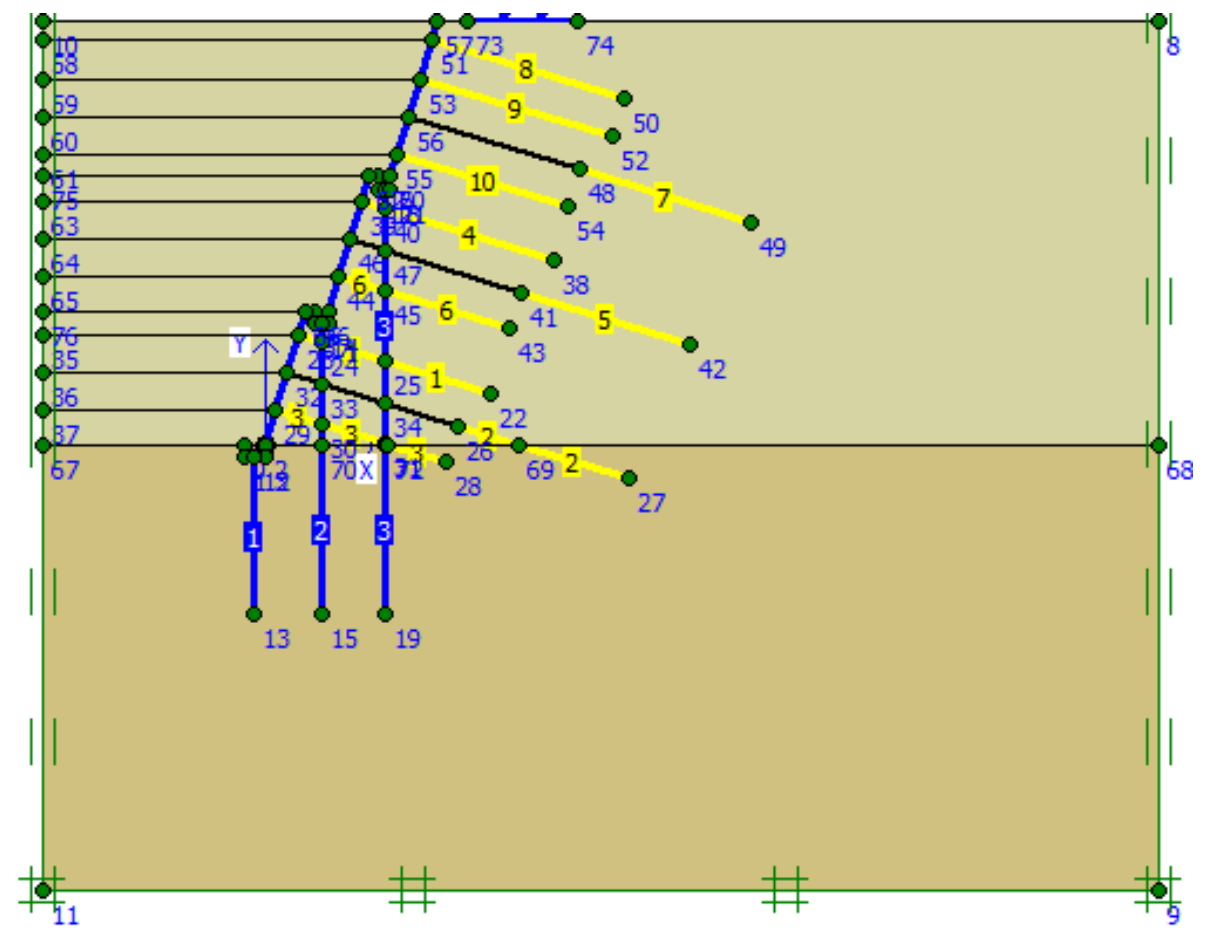

Figure 4. The typical numerical model calculation for the $3^{\text {rd }} 4^{\text {th }}$ sections. 
In order to evaluate the long term performance of the slope, a worst-case scenario in which the groundwater table rises to a level of +47.00 was evaluated. The groundwater flow conditions are presented in Figure 5. The size of the model was made large enough in such a way that the boundary condition does not affect the computed results. The computation process took a total number of 22 steps. To make it easy to follow the steps of the procedure are listed in Table 2.

\subsection{Geotechnical safety modelling results}

The computation of geotechnical safety was performed to evaluate expected lateral

Table 2. Calculation steps applied in modeling.

\begin{tabular}{|c|c|}
\hline Step no & Step definition \\
\hline 1 & $\begin{array}{l}1^{\text {st }} \text { layer excavation (ground level) to } \\
\text { the depth of soil nail SN.7 row }\end{array}$ \\
\hline 2 & $\begin{array}{l}\text { Nail holes drilling and installation for } \\
\text { SN7 row, application of shotcrete }\end{array}$ \\
\hline 3 & $2^{\text {nd }}$ layer excavation \\
\hline 4 & $2^{\text {nd }}$ nail row (SN6) installation \\
\hline 5 & $3^{\text {rd }}$ layer excavation \\
\hline 6 & $3^{\text {rd }}$ nail row (SN5) installation SN5 \\
\hline 7 & $4^{\text {th }}$ layer excav. down to +47.00 \\
\hline 8 & $\begin{array}{l}\text { Micropile (D325, 19.0m) installation, } \\
\text { beam and } 400 \mathrm{~mm} \text { concrete facing }\end{array}$ \\
\hline 9 & $5^{\text {th }}$ layer excavation \\
\hline 10 & $4^{\text {th }}$ nail row installation, SN4; \\
\hline 11 & $6^{\text {th }}$ layer excavation \\
\hline 12 & Execute the fifth nail row, SN3; \\
\hline 13 & 7 th layer excavation down to +41.00 \\
\hline 14 & $\begin{array}{l}\text { Micropile (D325, 13.0m) installation, } \\
\text { beam and } 400 \mathrm{~mm} \text { concrete facing }\end{array}$ \\
\hline 15 & $8^{\text {th }}$ layer excavation \\
\hline 16 & 6th nail row (SN2) installation; \\
\hline 17 & 9th layer excavation \\
\hline 18 & $7^{\text {th }}$ nail row (SN1) installation; \\
\hline 19 & $\begin{array}{l}\text { Excavate the } 10 \text { th layer down to the } \\
\text { level of }+35.00\end{array}$ \\
\hline 20 & $\begin{array}{l}\text { Micropile (D325, } 13.0 \mathrm{~m}) \text { installation, } \\
\text { beam and } 400 \mathrm{~mm} \text { concrete facing }\end{array}$ \\
\hline 21 & $\begin{array}{l}\text { Micropile (D325, } 13.0 \mathrm{~m}) \text { installation, } \\
\text { beam and } 400 \mathrm{~mm} \text { concrete facing; }\end{array}$ \\
\hline 22 & $\begin{array}{l}\text { Anchor stressing, } 250 \mathrm{kN}, 260 \mathrm{kN}, 250 \\
\mathrm{kN} \text {. }\end{array}$ \\
\hline
\end{tabular}

displacements and overall Factor of Safety (FS). The approach used for FS computation was shear strength reduction (Farshidfar et al., 2015). The method allows generating out-of-balance forces that are solved using a calculation kernel that results in deformation. These additional displacements that are generated do not have a physical meaning, but the incremental displacements or incremental shear strains in the final calculation step, indicate the likely failure mechanism. The computations were performed for all the sections described (Section No 1-4). According to (Peck, 1969), to restrain the strain level of the backfill and to maintain the stability of the retaining wall the wall displacements should be smaller than the value at the failure. The value at the failure is considered less that $\mathrm{H} / 60$ where $\mathrm{H}$ is the wall height. For the factor of safety higher than 2 the value becomes H/150-200. The maximum computed lateral displacement for Section No 1 and 2 found to fall in the acceptable range of $\mathrm{U}_{\mathrm{x}}=37 \times 10^{-3} \mathrm{~m} \sim 3.7 \mathrm{~cm}<[\delta]=\mathrm{H} /(150$ $200)=(7.8-10) \mathrm{cm}$ as recommended in (Peck, 1969), where $H=15$ is the height of the slope. For section no 3 and 4 the computed displacements where significantly higher (by as much as 35\%) but this is simply due to different slope geometry displacements, $\mathrm{U}_{\mathrm{x}}=50 \times 10^{-3} \mathrm{~m} \sim 5.0 \mathrm{~cm}<[\delta]=$ $\mathrm{H} /(150-200)=8.5-11.5) \mathrm{cm}$, where $\mathrm{H}=15$ is the height of the slope. The computation results for sections 3 and 4 are presented in Figure 6.

The geotechnical safety computations also involved numerical analyses of the factor of safety. The results differ for each section but they all proved that the proposed solutions give satisfying FS falling in a range of 1.59 (sections 3 and 4) to 1.67 (sections 1 and 2). Adopting recommended FS value for high risk stricter being 1.45 the case study and the solution proposed could be considered as safe from a geotechnical point of view. The computation captured during the calculation process is presented in Figure 7.

Additional calculations were performed to verify bending moment distributions in each slopes' face (concrete $400 \mathrm{~mm}$ layers). The example results for each facing $(1,2,3)$ of sections 3 and 4 are shown in Figure 8. The extreme bending moments showed acceptable values ranging from 137.37 to $204.40 \mathrm{kNm} / \mathrm{m}$. 


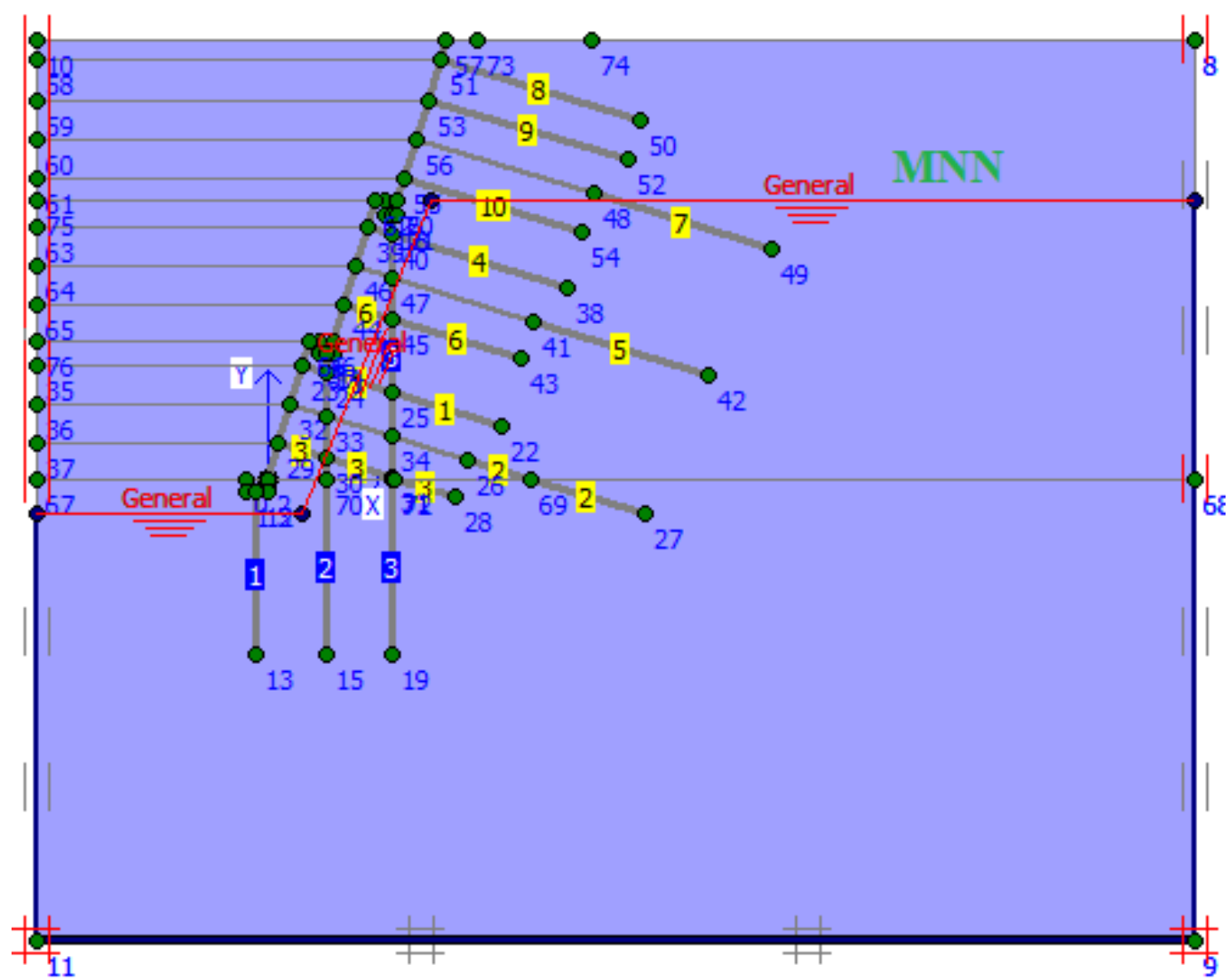

Figure 5. Changed groundwater table conditions.

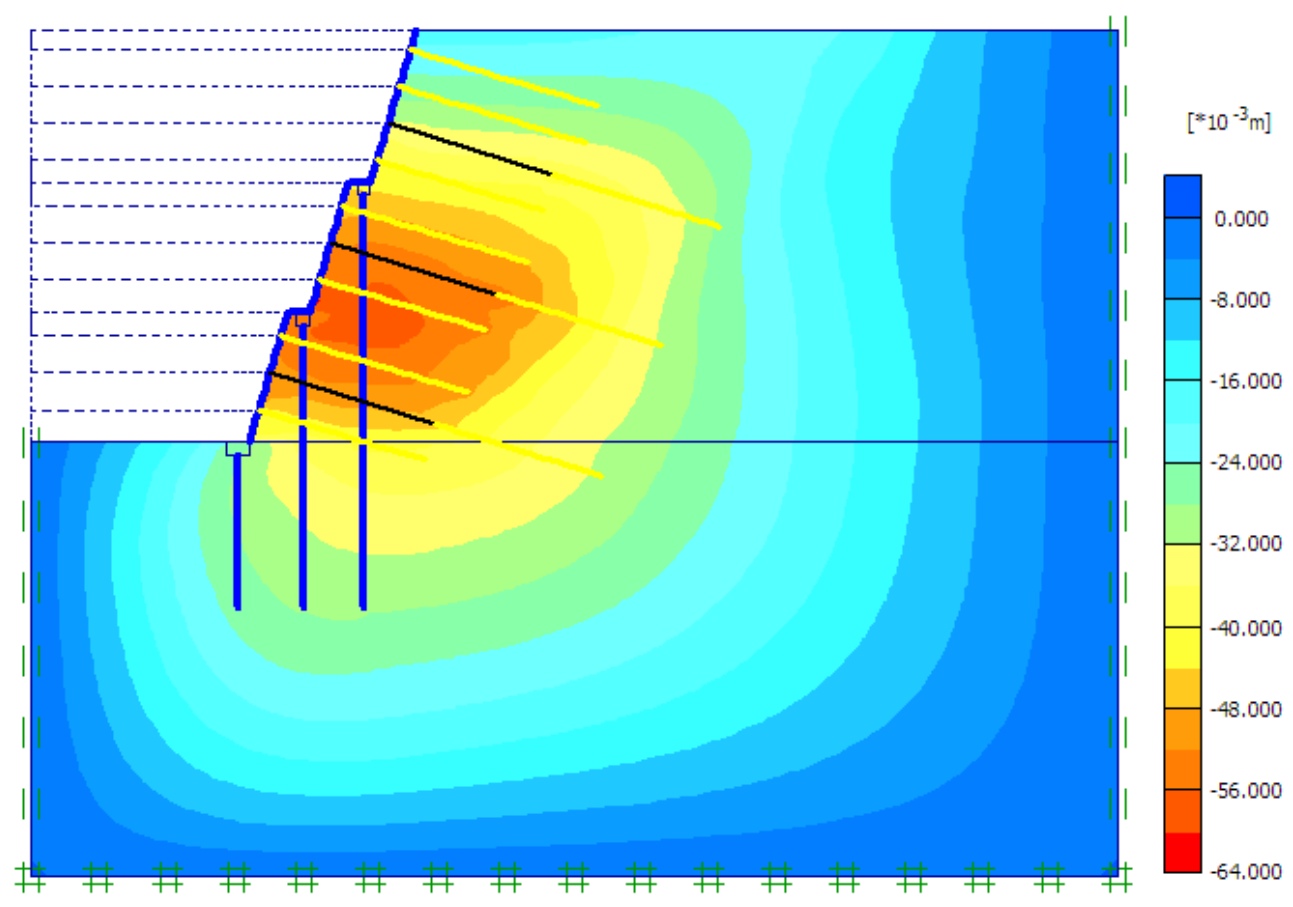

Horizontal displacements (Ux)

Figure 6. Distribution of lateral displacement of the in sections 3 and 4. 


\begin{tabular}{|c|c|c|c|c|c|c|}
\hline \multicolumn{7}{|l|}{ General | Parameters Multipliers | Preview | } \\
\hline \multirow{9}{*}{$\begin{array}{l}\text { Show } \\
\text { C Input values } \\
C \text { Reached values }\end{array}$} & \multicolumn{3}{|c|}{ Incremental multipliers } & \multicolumn{3}{|c|}{ Total multipliers } \\
\hline & Mdisp: & 0.0000 & $\hat{\nabla}$ & $\Sigma$-Mdisp: & 1.0000 & 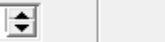 \\
\hline & MloadA: & 0.0000 & 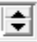 & $\Sigma$-MloadA: & 1.0000 & 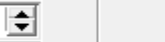 \\
\hline & MloadB: & 0.0000 & $=$ & $\Sigma$-MloadB: & 1.0000 & $\Leftrightarrow$ \\
\hline & Mweight: & 0.0000 & -1 & $\Sigma$-Mweight: & 1.0000 & 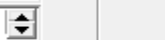 \\
\hline & Maccel: & 0.0000 & $\rightarrow$ & I-Maccel: & 0.0000 & 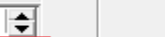 \\
\hline & Msf: & 0.1000 & 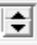 & $\Sigma$-Msf: & 1.5902 & $\underline{-1}$ \\
\hline & & & & \multicolumn{3}{|c|}{$\mathrm{FS}=1.59>[\mathrm{FS}]=1.45$} \\
\hline & & & & \multicolumn{2}{|c|}{ 罚 Next } & 兽 Insert \\
\hline Identification & & & & Phase no. & Start from & Calculation \\
\hline $\mathscr{V}<$ Phase 14> & & & & 14 & 13 & Plastic analysis \\
\hline $\mathscr{V}<$ Phase $15>$ BTCT 400 (Mái 2) + Móng & & & & 15 & 14 & Plastic analysis \\
\hline $\mathscr{d}<$ Phase $16>$ Micropile $13 \mathrm{~m}$ & & & & 16 & 15 & Plastic analysis \\
\hline $\mathscr{V}\langle$ Phase 17> & & & & 17 & 16 & Plastic analysis \\
\hline $\mathscr{d}<$ Phase $18>$ SN6 & & & & 18 & 17 & Plastic analysis \\
\hline $\mathscr{V}\langle$ Phase 19> & & & & 19 & 18 & Plastic analysis \\
\hline $\mathscr{d}<$ Phase $20>$ SN7 & & & & 20 & 19 & Plastic analysis \\
\hline $\mathscr{V}<$ Phase 21> & & & & 21 & 20 & Plastic analysis \\
\hline $\mathscr{V}<$ Phase $22>$ BTCT 400 Mái 3 & & & & 22 & 21 & Plastic analysis \\
\hline $\mathscr{V}\langle$ Phase 23> & & & & 23 & 22 & Plastic analysis \\
\hline $\mathscr{I}$ <Phase $24>\mathrm{NeO} 3-250 \mathrm{kN}$ & & & & 24 & 23 & Plastic analysis \\
\hline $\mathscr{V}<$ Phase $25>$ Neo $2-270 \mathrm{kN}$ & & & & 25 & 24 & Plastic analysis \\
\hline $\mathscr{d}<$ Phase $26>$ Neo $1-250 \mathrm{kN}$ & & & & 26 & 25 & Plastic analysis \\
\hline :: <Phase $27>$ Hệ sô ốn đinh tống thế & & & & 27 & 26 & Phi/creduction \\
\hline
\end{tabular}

Figure 7. Overall stability analysis result of the proposed approach for sections 3 and 4.
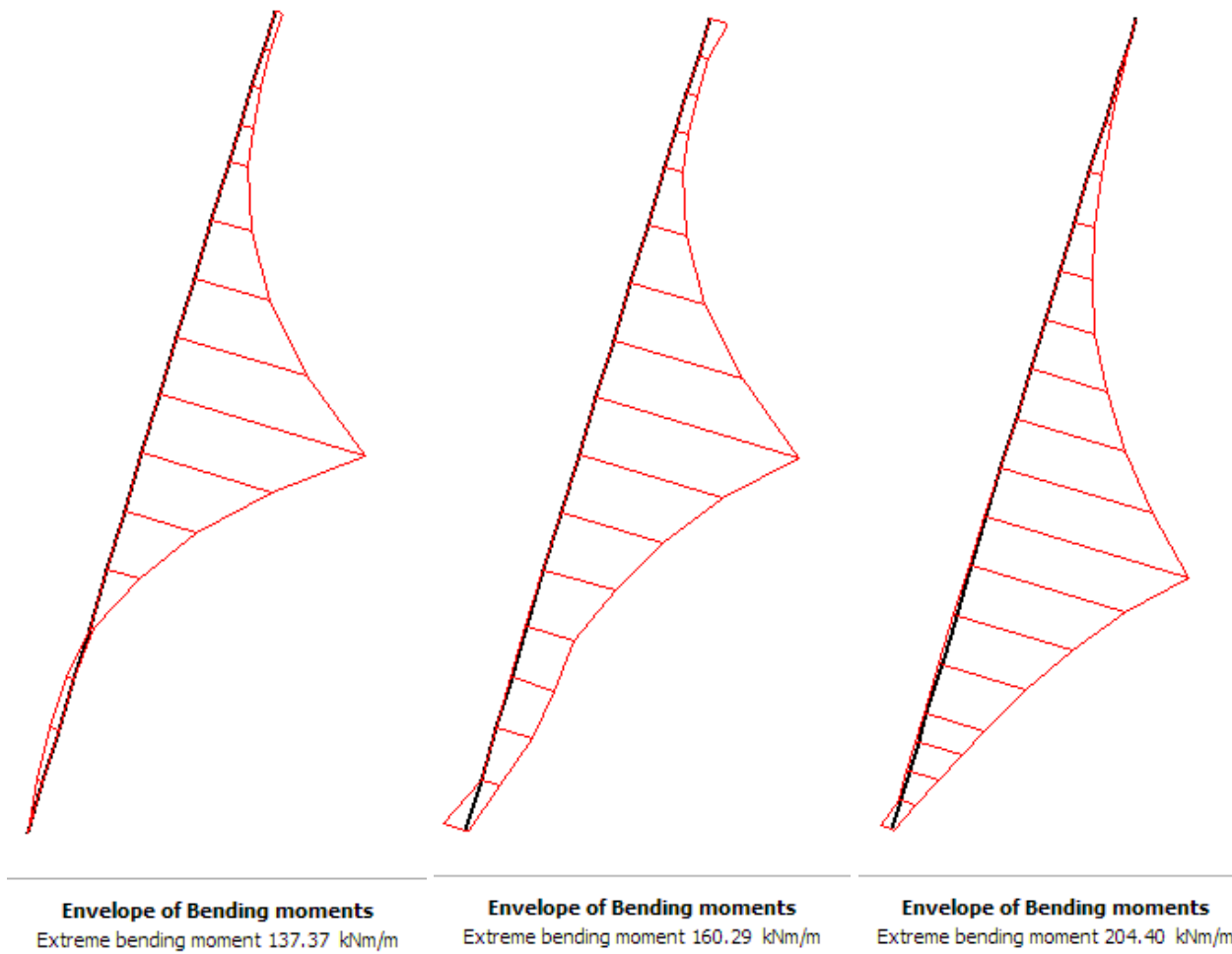

Figure 8. Slope's face bending moment distribution: $a$ - Face No. 1 b-Face No. 2, cFace No. 3. 


\section{Conclusion}

The rapid economic development of Viet Nam is positively affecting all the national sectors. This includes infrastructures that need safe designing solutions to serve their purpose. New investments often require complex approaches, that would meet the development demand. This concerns the civil engineering sector too, which geotechnical engineering is a crucial part of. The present paper investigates the geotechnical safety of an engineered slope requiring significant and sophisticated reinforcements. Using numerical calculations and models allowing incorporating proposed stability improvement showed the geotechnical safety was met at every phase of the earthworks process. The predicted displacements and computed factors of safety proved the correctness of the proposed complex reinforcing solution, combining soil nails, ground anchors and micro piles. The present case study demonstrated that unusual construction site conditions need to be tackled by a combination of complex approaches.

\section{Acknowledgements}

The authors would like to acknowledge the support of Fucons Foundation and Underground, and Bamboo company for providing the data for the research and analyses, and the assistance during the preparation of the paper.

\section{Author contributions}

NAP contributed $10 \%$ during the preparation of the paper by reviewing and editing the content. PO conceived, wrote and edited the paper and contributed $20 \%$. NAD contributed $10 \%$ by providing expertise advice during the preparation. EK assisted in the analytical evaluation of the results and contributed $10 \%$. MNV contributed $15 \%$ by reviewing and giving critical feedback. DVB conceived the paper and performed the calculation and contributed to editing giving $20 \%$ of the contribution. NTV contributed $15 \%$ by providing the data for analysis.

\section{References}

Babu, G. S., Murthy, B. S., Murthy, D. S. N., \& Nataraj, M. S. (2004). Bearing capacity improvement using micropiles: A case study. GeoSupport, 692-699.

Bayesteh, H., Fakharnia, M. A., \& Khodaparast, M.,(2021). Performance of Driven Grouted Micropiles: Full-Scale Field Study. International Journal of Geomechanics, 21(2), 04020250.

Berglund, E. Z., Monroe, J. G., Ahmed, I., Noghabaei, M., Do, J., Pesantez, J. E., ... \& Levis, J. (2020). Smart infrastructure: a vision for the role of the civil engineering profession in smart cities. Journal of Infrastructure Systems, 26(2), 03120001.

Blanco-Fernandez, E., Castro-Fresno, D., Díaz, J. D. C., \& Lopez-Quijada, L. (2011). Flexible systems anchored to the ground for slope stabilisation: Critical review of existing design methods. Engineering Geology, 122(3-4), 129-145.

Brinkgreve, R. B. J., Swolfs, W. M., Engin, E., Waterman, D., Chesaru, A., Bonnier, P. G., \& Galavi, V. (2010). PLAXIS 2D 2010. User manual, Plaxis bv.

Crosta, G. B., \& Frattini, P. (2008). Rainfallinduced landslides and debris flows. Hydrological Processes: An International Journal, 22(4), 473-477.

Dai, F. C., Lee, C. F., \& Ngai, Y. Y. (2002). Landslide risk assessment and management: an overview. Engineering geology, 64(1), 65-87.

Dhar, U. (2021). Asian Development Bank (ADB), What Drives Innovation in Asia? Asian Development Outlook 2020.

Elia, G., Cotecchia, F., Pedone, G., Vaunat, J., Vardon, P. J., Pereira, C., ... \& Osinski, P. (2017). Numerical modelling of slope-vegetationatmosphere interaction: an overview. Quarterly Journal of Engineering Geology and Hydrogeology, 50(3), 249-270.

Ellis, I. W. (2020). Ground anchors. In The Maintenance of Brick and Stone Masonry Structures (pp. 271-281). CRC Press. 
Farshidfar, N., \& Nayeri, A. (2015). Slope stability analysis by shear strength reduction method. Civil Engineering and Urbanism Journal, 5, 35-37.

Fredlund, D. G., Xing, A., Fredlund, M. D., \& Barbour, S. L. (1996). The relationship of the unsaturated soil shear strength to the soilwater characteristic curve. Canadian geotechnical journal, 33(3), 440-448.

Lazarte, C. A., Robinson, h., \& Gómez, J. (2015). Soil Nail Walls Reference Manual: FHWA-NHI14-007.

Nguyen, P. N., Woo, S. H., Beresford, A., \& Pettit, S. (2020a). Competition, market concentration, and relative efficiency of major container ports in Southeast Asia. Journal of Transport Geography, 83, 102653.

Nguyen, P. T., Likhitruangsilp, V., \& Onishi, M. (2020b). Success factors for public-private partnership infrastructure projects in Vietnam. International Journal on Advanced Science, Engineering and Information Technology, 10(2), 858-865.

Osiński, P., Dobrzelewski, B., Koda, E., \& Król, P. (2020). Slope stability analyses incorporating soil improvement methods for valuable urban area. In Geotechnics for Sustainable Infrastructure Development (pp. 803-808). Springer, Singapore.

Peck, R.B. (1969). Deep Excavation and Tunneling in Soft Ground. State-of-the-Art Report. Proceedings of the 7th International Conference on Soil Mechanics and Foundation Engineering, Mexico, 225-325.
Rahardjo, H., Hritzuk, K. J., Leong, E. C., \& Rezaur, R. B. (2003). Effectiveness of horizontal drains for slope stability. Engineering Geology, 69(3-4), 295-308.

Seah, S., Ha, H. T., Martinus, M., \& Thao, P. T. P. (2021). The state of Southeast Asia: 2021 survey report.

Tang, A. M., Hughes, P. N., Dijkstra, T. A., Askarinejad, A., Brenčič, M., Cui, Y. J., \& Van Beek, V. (2018). Atmosphere-vegetation-soil interactions in a climate change context; impact of changing conditions on engineered transport infrastructure slopes in Europe. Quarterly Journal of Engineering Geology and Hydrogeology, 51(2), 156-168.

Thyagaraj, T. (2019). Ground Improvement Techniques and Geosynthetics. Springer: Berlin, Germany.

Wan, S., Nian, T., Jiang, J., \& Luan, M. T. (2010). Discussion on several issues in slope stability analysis based on shear strength reduction finite element methods (SSR-FEM). Rock and Soil Mechanics, 31(7), 2283-2290.

Zettler, A. H., Poisel, R., Roth, W., \& Preh, A. (2020). Slope stability analysis based on the shear reduction technique in 3D. In FLAC and Numerical Modeling in Geomechanics (pp. 11-16). CRC Press.

Zhang, C., Lijun, S. U., Weizhi, C. H. E. N., \& Jiang, G. (2021). Full-scale performance testing of bored piles with retaining walls in high cutting slope. Transportation Geotechnics, 29, 100563. 